\title{
Validated stability indicating gradient RP-HPLC method for the estimation of antihypertensive drugs in bulk and pharmaceutical dosage forms
}

\author{
*Napa Delhi Raj ${ }^{1}$, Sockalingam Anbazhagan², Kunapareddy Anudeep Babu³, Sunkara Narendra Babu", \\ Chusena Narasimharaju Bhimanadhuni ${ }^{5}$ \\ ${ }^{1}$ Research Scholar, Aacharya Nagarjuna University, Nagarjuna Nagar, Guntur, Andhra Pradesh, India \\ ${ }^{2}$ Department of Pharmaceutical analysis, Karuna College of pharmacy, Iringuttoor, Kerala, India \\ ${ }^{3}$ Department of Pharmaceutical analysis, Nimra College of pharmacy, Nimra nagar, Jupudi-521456, Vijayawada, Andhra Pradesh, India \\ ${ }^{4}$ Analytical Research Division, Cystron pharmaceutical laboratories, Vijayawada, Andhra Pradesh, India \\ ${ }^{5}$ Department of Pharmaceutical analysis, Annabattuni Satya Narayana Pharmacy College, Burripalem Road, Tenali-522201, Guntur (Dt), \\ Andhra Pradesh, India
}

\begin{abstract}
A rapid and precise RP-HPLC method for determination of Olmesartan medoxomil and Hydrochlorothiazide in bulk and pharmaceutical dosage forms. Olmesartan medoxomil \& Hydrochlorothiazide are found to be degraded together under different set of conditions as followed according to $\mathrm{ICH}$ guidelines and the degradants so formed along with olmesartan \& hydrochlorothiazide are separated by using INERTSIL ODS C18 3V $(150 \times 4.6,5 \mu)$ using mobile phase $1 \mathrm{ml}$ triethanolamine in one litre water and the $\mathrm{pH}$ was adjusted to 2.5 with orthophosphoric acid and acetonitrile using a gradient program with a flow rate of $1 \mathrm{ml} / \mathrm{min}$, throughout the gradient program with a detection wavelength of $225 \mathrm{~nm}$ for both the compounds with a injection volume of $10 \mu \mathrm{l}$. The method was validated for selectivity, linearity, accuracy, robustness, precision and specificity. The results were indicating the method was selective in analysis of both olmesartan medoxomil and hydrochlorothiazide in the presence of degradation products formed under various stress conditions.
\end{abstract}

Key Words: Olmesartan medoxomil, Hydrochlorothiazide, INERTSIL ODS C18, Orthophosphoric acid, Acetonitrile, ICH Guidelines.

\section{INTRODUCTION}

Olmesartan medoxomil (Figure 1) chemically it is 4(1-Hydroxy-1-methylethyl)-2-propyl-1-[[2'-(1H-

tetazol-5-yl) [1, 1'-biphenyl]-4-yl] methyl]-1Himidazole-5-carboxylic acid (5-Methyl-2-oxo-1, 3dioxol-4-yl) methyl ester. It works by blocking a substance in the body that causes blood vessels to tighten. As a result, olmesartan relaxes blood vessels. This lowers blood pressure and increases the supply of blood and oxygen to the heart (The Merck Index). Hydrochlorothiazide (Figure 2) is 6-Chloro-3, 4dihydro-2H-1, 2, 4-benzothiadiazine-7-sulfonamide 1, 1-dioxide. It reduces the amount of water in the body by increasing the flow of urine, which helps

\footnotetext{
*Corresponding Author:

Napa Delhi Raj, Associate Professor

Department of Pharmaceutical analysis

A.S.N Pharmacy College, Burripalem Road

Tenali-522201, Guntur (Dt), Andhra Pradesh, India

E-mail: pharmaraj1981@gmail.com

Contact No.: 8985351361
}

lower the blood pressure (Black, 2009).Olmesartan medoxomil and Hydrochlorothiazide are introduced into the market in combined dosage form, which is widely used in the treatment of hypertension. Literature review reveals that the methods for olmesartan and hydrochlorothiazide alone or in combined dosage forms are Development and Validation of Spectrophotometric and RP-HPLC Method for Estimation of Olmesartan Medoxomil in Tablet dosage form (Jain et al., 2010).Validated Absorption Factor Spectrophotometric and Reversed-Phase High Performance Liquid Chromatographic Methods for the Determination of Ramipril and Olmesartan Medoxomil in Pharmaceutical Formulations (Chintan V. Patela et al 2007). Development of UV Spectrophotometric method for the simultaneous estimation of olmesartan Medoxomil and atorvastatin calcium in tablet by simultaneous equation and first order derivative method (Nagavalli et al., 2011). Development and 


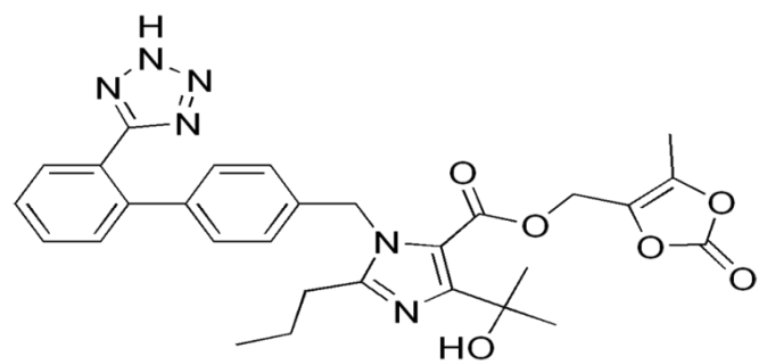

Figure 1: Structure of Olmesartan medoximil.

validation of Spectrophotometric method for simultaneous estimation of Metoprolol succinate and Olmesartan medoxomil in Tablets (Vachhani et al., 2011). Simultaneous Quantitation of Olmesartan medoxomil and Amlodipine Besylate in Combined Tablets Using HPLC (Syed et al., 2009). Spectrophotometric Method for Simultaneous determination of Olmesartan medoxomil and Amlodipine Besylate from Tablet dosage forms (Pournima Patil et al., 2011). UV spectrophotometric Determination of Hydrochlorothiazide and Olmesartan Medoxomil in pharmaceutical Formulation (Hemke et al., 2010). Spectrophotometric Estimation of Olmesartan Medoxomil and Hydrochlorthiazide in Tablet (Rote et al., 2010). Spectrophotometric Simultaneous Determination of Hydrochlorothiazide and Telmisartan in Combined Dosage Form (Rekha et al., 2010). RP-HPLC Method for Simultaneous Estimation of Telmisartan \& Hydrochlorothiazide in Tablet Dosage Forms (Wankhede et al., 2008). A Validated Stability Indicating HPTLC Method for Simultaneous Estimation of Irbesartan and Hydrochlorothiazide (Amol et al., 2010). Simultaneous Analysis of Eprosatan and Hydrochlorothiazide in Tablets by HPLC (Harsha U. Patel et al., 2011). Development and Validation of a RP-HPLC for the Simultaneous Estimation of Atenolol and Hydrochlorothiazide in Pharmaceutical Dosage Forms (Zaveri et al., 2010).Simultaneous Estimation of Nebivolol and Hydrochlorothiazide in combined tablet dosage form by Multicomponent Mode of analysis (Tarte et al., 2008). Spectrophotometric Simultaneous Determination of Amlodipine Besylate And Hydrochlorothiazide In Combined Tablet Dosage Form By Simultaneous Equation, Absorption Ratio And First Order Derivative Spectroscopy Methods(Vijaya et al., 2011).

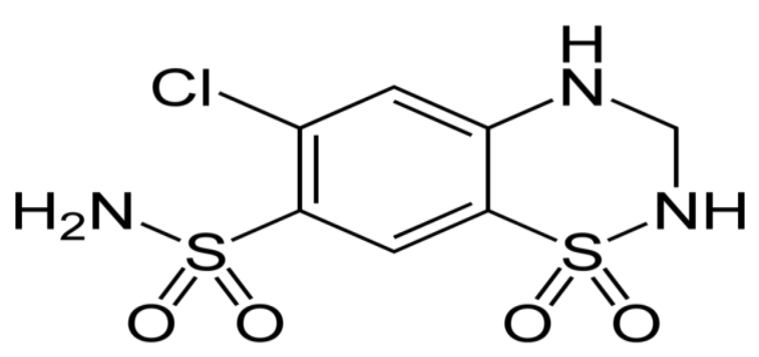

Figure 2: Structure of Hydrochlorothiazide.

\section{EXPERIMENTAL}

Chromatographic Conditions: Olmesartan medoxomil \& hydrochlorothiazide reference standards was supplied by M/s Microlabs limited, Bangalore, India. HPLC grade Acetonitrile was purchased from Merck (Mumbai, India) and triethanolamine and orthophosphoric acid from Merck (Mumbai, India). All chemicals were of analytical grade. The determination was carried out on Waters HPLC 2690 equipped with PDA 996 as detector using data handling system - waters empower 2.0 software. The column used in the development for the determination is INERTSIL ODS C18 $(150 \times 4.6,5 \mu)$. The detector wavelength was set at $225 \mathrm{~nm}$ for both the components. A flow rate of $1 \mathrm{ml} / \mathrm{min}$ was used for the determination of olmesartan and hydrochlorothiazide. The samples and standards were dissolved in diluent (water: $\mathrm{ACN}, 30: 70$ ) and $10 \mu \mathrm{L}$ sample were injected into HPLC system at the column and sample temperature of $30^{\circ} \mathrm{C}$.

\section{Mobile phase}

$1.0 \mathrm{ml}$ of Triethanolamine was mixed with $1000 \mathrm{~mL}$ of milli $\mathrm{Q}$ water and $\mathrm{pH}$ was adjusted to $2.5 \pm 0.05$ with Orthophospharic acid, filtered through $0.45 \mu \mathrm{m}$ Membrane filter. pH 2.5 Triethanolamine: Acetonitrile mixture used as a mobile phase injected into the system through a gradient flow indicated in Table 1.

Table 1: Gradient Program.

\begin{tabular}{cccc}
\hline $\begin{array}{c}\text { Time } \\
\text { (min) }\end{array}$ & $\begin{array}{c}\text { Flow Rate } \\
\text { ml/min }\end{array}$ & $\begin{array}{c}\text { \%Mobile Phase A } \\
\text { (pH 2.5 Triethanolamine) }\end{array}$ & $\begin{array}{c}\text { \%Mobile Phase B } \\
\text { (Acetonitrile) }\end{array}$ \\
\hline 0 & 1 & 75 & 25 \\
5 & 1 & 50 & 50 \\
7 & 1 & 50 & 50 \\
8 & 1 & 75 & 25 \\
12 & 1 & 75 & 25 \\
\hline
\end{tabular}


Table: 2 Method Development conditions.

\begin{tabular}{|c|c|c|c|c|c|}
\hline Trial & Type of column & Mobile phase composition & $\begin{array}{l}\text { Injection } \\
\text { volume }\end{array}$ & Flow & Defect \\
\hline 1 & $\mathrm{C}_{18}(150 \times 4.6), 5 \mu \mathrm{m}$ & $\begin{array}{l}\text { Isocratic } \\
\text { Water : Methanol (40:60) }\end{array}$ & $20 \mu l$ & $1 \mathrm{ml} / \mathrm{min}$ & $\begin{array}{l}\text { More Rt \& less no. of theoretical } \\
\text { plates }\end{array}$ \\
\hline 2 & $\mathrm{C}_{18}(150 \times 4.6), 5 \mu \mathrm{m}$ & $\begin{array}{l}\text { Isocratic } \\
\text { Water : Acetonitrile (30: 70) }\end{array}$ & $20 \mu \mathrm{l}$ & $1 \mathrm{ml} / \mathrm{min}$ & $\begin{array}{l}\text { Split peeks, less number of } \\
\text { theoretical plates }\end{array}$ \\
\hline 3 & $\mathrm{C}_{18}(150 \times 4.6), 5 \mu \mathrm{m}$ & $\begin{array}{l}\text { Isocratic } \\
\text { Methanol:acetonitrile (40:60) }\end{array}$ & $20 \mu \mathrm{l}$ & $1 \mathrm{ml} / \mathrm{min}$ & More Rt \\
\hline 4 & $\mathrm{C}_{18}(150 \times 4.6), 5 \mu \mathrm{m}$ & $\begin{array}{l}\text { Isocratic } \\
\text { Buffer: Acetonitrile (30: 70) }\end{array}$ & $20 \mu \mathrm{l}$ & $1 \mathrm{ml} / \mathrm{min}$ & Resolution was not so good \\
\hline 5 & $\mathrm{C}_{18}(150 \times 4.6), 5 \mu \mathrm{m}$ & $\begin{array}{l}\text { Gradient } \\
\text { Buffer (pH 3.5): Acetonitrile }\end{array}$ & $20 \mu \mathrm{l}$ & $1 \mathrm{ml} / \mathrm{min}$ & Resolution was not so good \\
\hline 6 & $\mathrm{C}_{18}(150 \times 4.6), 5 \mu \mathrm{m}$ & $\begin{array}{l}\text { Gradient } \\
\text { Buffer (pH 2.5):Acetonitrile }\end{array}$ & $20 \mu \mathrm{l}$ & $1 \mathrm{ml} / \mathrm{min}$ & $\begin{array}{l}\text { Less Rt, More theoretical plates, } \\
\text { less tailing, symmetrical peek } \\
\text { shape, Good resolution }\end{array}$ \\
\hline
\end{tabular}

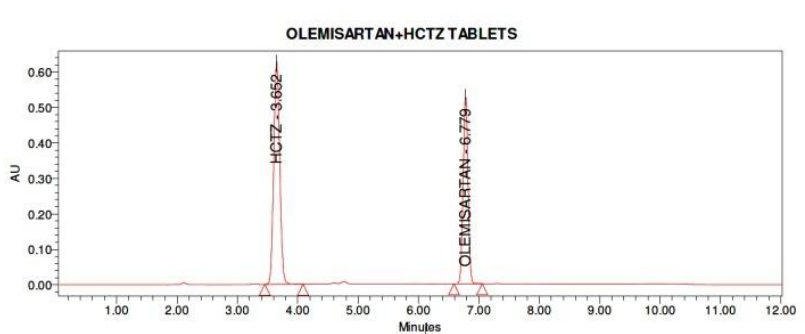

Figure 3: Sample chromatogram for Hydrochlorothiazide and Olmesartan.

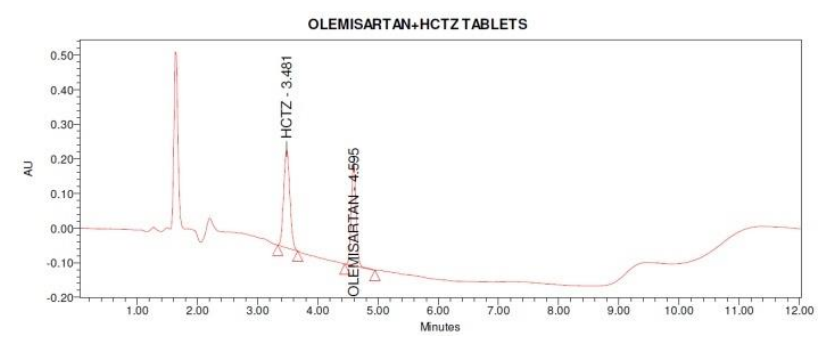

Figure 5: Basic degradation chromatogram of olmesartan \& hydrochlorothiazide.

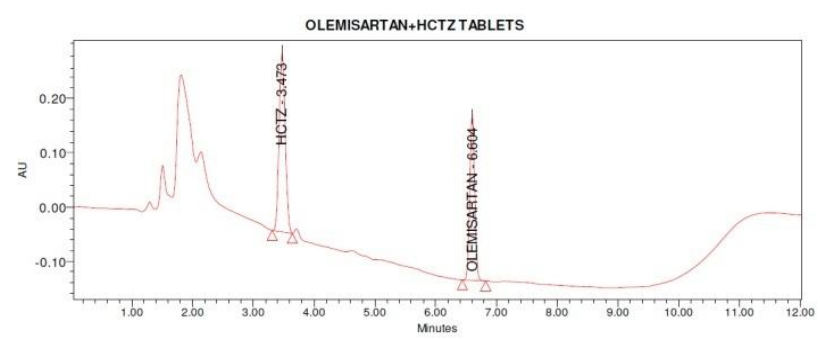

Figure 7: Reduction degradation chromatogram of olmesartan \& hydrochlorothiazide.

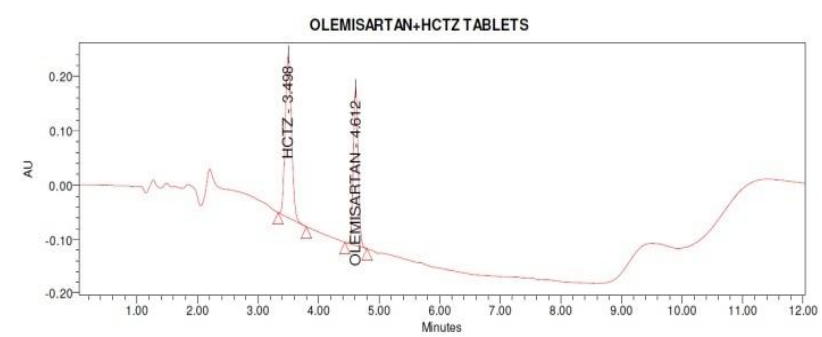

Figure 4: Acid degadation chromatogram of olmesartan \& hydrochlorothiazide.

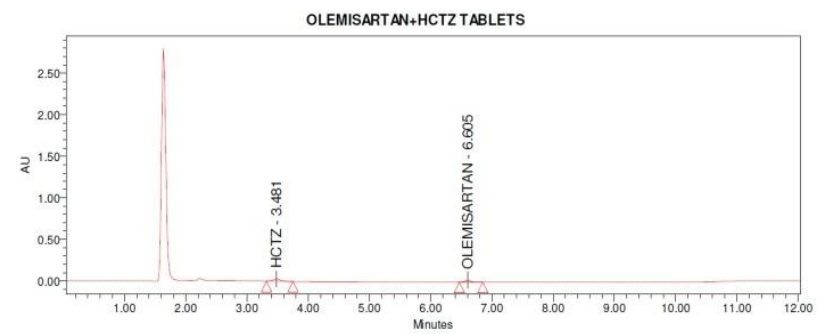

Figure 6: Peroxide degradation chromatogram of olmesartan \& hydrochlorothiazide.

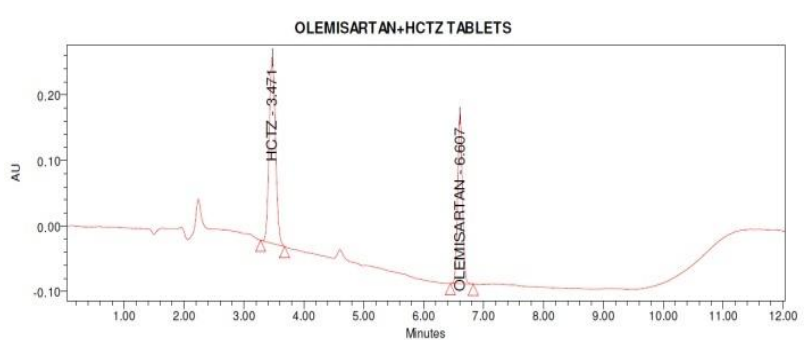

Figure 8: Thermal degradation chromatogram of olmesartan \& hydrochlorothiazide. 
Table 3: Assay of Olmesartan \& Hydrochlorothiazide.

\begin{tabular}{llcc}
\hline Brand name & Compound & $\begin{array}{c}\text { Amount } \\
\text { found (mg) }\end{array}$ & \% Assay \\
\hline \multirow{2}{*}{ OLSAR-H } & Olmesartan & 20.04 & 100.2 \\
& Hydrochlorothiazide & 12.7 & 101.7 \\
\hline OLMEZEST- & Olmesartan & 20.1 & 100.5 \\
H-20 & Hydrochlorothiazide & 12.7 & 101.6 \\
\hline
\end{tabular}

Table 4: Precision studies for Olmesartan \& Hydrochlorothiazide.

\begin{tabular}{llll}
\hline Compound & \% Assay & \% RSD of & $\begin{array}{l}\text { \% Assay } \\
\text { (Day-2, Analyst-2, Instrument-2) }\end{array}$ \\
& (Day-1, Analyst-1, Instrument-1) & Assay (N=6) & Assay (N=6) \\
\hline Olmesartan medoximil & 99.45 & 0.26 & 99.40 \\
Hydrochlorothiazide & 100.3 & 0.31 & 100.6 \\
\hline
\end{tabular}

Table 5: Recovery studies for Olmesartan \& Hydrochlorothiazide.

\begin{tabular}{llccc}
\hline Drug & $\begin{array}{l}\text { Amount } \\
\text { recovered (mg) }\end{array}$ & \% recovery & $\begin{array}{c}\text { Mean \% } \\
\text { recovery }\end{array}$ & \% RSD \\
\hline Olmesartan & 100.80 & 99.8 & & 0.170 \\
medoximil & 200.03 & 99.5 & 99.8 & 0.080 \\
& 300.50 & 99.5 & & 0.030 \\
\hline Hydrochlo- & 63.20 & 99.5 & & 0.160 \\
rothiazide & 125.70 & 99.7 & 99.60 & 0.170 \\
& 187.60 & 99.5 & & 0.170 \\
\hline
\end{tabular}

Table 6: Stability studies for Olmesartan \& Hydrochlorothiazide.

\begin{tabular}{lllll}
\hline Experiment & & \% Degradation & Purity Angle & Purity Threshold \\
\hline Acid & Olmesartan & 25.9 & 0.024 & 1.085 \\
$(1 \mathrm{~N} \mathrm{HCL}, 1 \mathrm{ml})$ & Hydrochlorothiazide & 26.8 & 0.022 & 1.058 \\
\hline Alkali & Olmesartan & 22.6 & 0.095 & 1.041 \\
$(1 \mathrm{~N} \mathrm{NaOH}, 1 \mathrm{ml})$ & Hydrochlorothiazide & 27.1 & 0.023 & 1.022 \\
\hline Oxidation & Olmesartan & 26.7 & 0.051 & 1.005 \\
$\left(30 \% \mathrm{H}_{2} \mathrm{O}_{2}, 2 \mathrm{ml}\right)$ & Hydrochlorothiazide & 27.1 & 0.099 & 1.072 \\
\hline Reduction & Olmesartan & 17.0 & 0.059 & 1.051 \\
$(10 \%$ Sodium bisulphate, $2 \mathrm{ml})$ & Hydrochlorothiazide & 27.2 & 0.039 & 1.095 \\
\hline Thermal & Olmesartan & 29.7 & 0.026 & 1.014 \\
$\left(\right.$ Heating at $70^{\circ} \mathrm{C}$ for $\left.1 \mathrm{hr}\right)$ & Hydrochlorothiazide & 27 & 0.044 & 1.066 \\
\hline
\end{tabular}

Table 7: Robustness studies for Olmesartan \& Hydrochlorothiazide.

\begin{tabular}{clcc}
\hline \multirow{2}{*}{$\begin{array}{c}\text { Sl. } \\
\text { No. }\end{array}$} & \multirow{2}{*}{ \%ondition } & 0.55 & 0.2 \\
\cline { 2 - 3 } 1 & Flow $(+20 \%)$ & 0.11 & 0.15 \\
2 & Flow $(-20 \%)$ & 0.29 & 0.06 \\
3 & Temperature $\left(35^{\circ} \mathrm{C}\right)$ & 0.21 \\
4 & Temperature $\left(40^{\circ} \mathrm{C}\right)$ & 0.3 & 0.2 \\
5 & Wavelength $(+5 \mathrm{~nm})$ & 0.29 & 0.38 \\
6 & Wavelength $(-5 \mathrm{~nm})$ & 0.13 & 0.68 \\
7 & pH of buffer 2.6 & 0.55 & 0.3 \\
8 & pH of buffer 2.4 & 0.25 & 0.32 \\
9 & Organic $(+2 \%)$ & 0.4 & 0.1 \\
10 & Organic $(-2 \%)$ & 0.25 & \\
\hline
\end{tabular}




\section{Preparation of standard and sample solutions}

Accurately weighed and transferred about $40 \mathrm{mg}$ of Olmesartan Medoxomil, $30 \mathrm{mg}$ of Hydrochlorothiazide working standards into two separate $100 \mathrm{ml}$ volumetric flasks, add about $70 \mathrm{ml}$ of diluent and sonicated to dissolve, cool the solution to room temperature \& dilute to the volume with diluent. $5 \mathrm{ml}$ of Olmesartan medoxomil standard stock solution, $4 \mathrm{ml}$ of Hydrochlorothiazide Standard Stock solution was transferred into $20 \mathrm{ml}$ volumetric flask and dilute to the volume with diluent.

Ten tablets were weighed and powdered uniformly in a mortar. An accurately weighed portion powder equivalent to $20 \mathrm{mg}$ of Olmesartan Medoxomil was transferred into a $250 \mathrm{ml}$ volumetric flask. $200 \mathrm{ml}$ of diluent was added, sonicated for 30 minutes with occasional stirring. Cool the solution to room temperature and dilute to the volume with diluent, filtered the solution through $0.45 \mu \mathrm{m}$ Teflon filter syringe. $3 \mathrm{ml}$ of the above filtered solution was transferred into a $25 \mathrm{ml}$ volumetric flask and diluted to the volume with diluent.

\section{RESULTS AND DISCUSSION}

The conditions tested for method development (Table 2) indicates that all the system suitability parameters according to ICH guidelines was achieved by using INERTSIL ODS C18 $(150 \times 4.6,5 \mu)$ column using mobile phase Triethanolamine in water and the $\mathrm{pH}$ was adjusted to 2.5 with Orthophosphoric acid and acetonitrile using a gradient program with a flow rate of $1 \mathrm{ml} / \mathrm{min}$ throughout the gradient program with a detection wavelength of $225 \mathrm{~nm}$ for both the compounds with a injection volume of $10 \mu \mathrm{l}$ (Figure 3 ).

To validate the RP-HPLC method, a series of tests were made using the most promising conditions. A calibration curve was made and concentration examined within the detection range of $25-150 \mu \mathrm{g} / \mathrm{ml}$ \& 15-90 $\mu \mathrm{g} / \mathrm{ml}$ for olmesartan \& hydrochlorothiazide and correlation coefficient was found to be 0.99988 \& 0.99984 for both the compounds respectively. The precision (expressed as the relative standard deviation (RSD) was determined for olmesartan \& hydrochlorothiazide for repeated analysis and the values are presented in Table 4 . The assay values obtained by proposed method and recovery expe- riment values obtained were performed by adding a fixed amount of drug to preanalysed formulation summarized in Table 3 and Table 5.

The stability of sample was checked by forced degradation in different conditions and \% of degradation was calculated. The peak purity of the analyte was passed in all conditions (purity angle should be less than the threshold value). The following values in Table 6 indicate that any other impurity is not merging with the main peak (Figure $4-8$ ). The analyte solution was stable up to $24 \mathrm{hrs}$. The reliability of the method was determined by made small deliberate variations in method parameters and the RSD values (Table 7) obtained, an indication of its reliability on normal usage. A method was developed for the determination of olmesartan \& hydrochlorothiazide in tablets which is rapid, stable \& specific. The results indicate that the described method can be used for quantitative analysis of the compounds.

\section{ACKNOWLEDGEMENT}

This work was supported by Cystron pharmaceutical laboratories. The authors are thankful to Principal, Dr. S. Duraivel, NIMRA College of Pharmacy, Vijayawada, Andhra Pradesh for encouragement and providing Support to carry out this research work.

\section{REFERENCES}

Amol S Khodke, Laxman V Potale, Mrinalini C Damle, Kailash G Bothara. (2010). A Validated Stability Indicating HPTLC Method for Simultaneous Estimation of Irbesartan and Hydrochlorothiazide. Pharmaceutical Methods; 1:3943.

Bari, P.D., Rote, A.R. (2009) RP-LC and HPTLC Methods for the determination of Olmesartan medoxomil and Hydrochlorothiazide in Combined Tablet Dosage Forms. Chromatographia; 69:1469-72. [DOI] PMid:19568313 PMCid:2701495

Black HR (2009) Triple fixed-dose combination therapy: back to the past. Hypertension. 54(1): 19-22. [DOI] PMid:19470871

Harsha U. Patel, Bhanubhai, N. Suhagia, Chhaganbhai N.Patel. (2011) Simultaneous Analysis of Eprosatan and Hydrochlorothiazide in Tablets by HPLC. Pharmaceutical Methods; 2:143-147. [DOI] 
Hemke, A.T. Bhure, M.V. Chouhan, K.S. Gupta, K.R. Wadodkar, S.G. (2010) UV Spectrophotometric determination of Hydrochlorothiazide and Olmesartan medoxomil in Pharmaceutical Formulation. E-Journal of Chemistry; 7(4): 1156-61. [DOI]

Jain, P., Jain, A., Maliwal, D., Jain, V (2010) Development and validation of spectrophotometric and RP-HPLC method for estimation of olmesartan medoxomil in Tablet Dosage Form. International Journal of Pharma and Bio Sciences, 1:1-7. [DOI] PMid:19819319

Nagavalli, D., Aluri, V.S.B. (2011) Development of UV Spectrophotometric method for the Simultaneous estimation of olmesartan medoxomil and atorvastatin calcium in tablet by simultaneous equation and first order derivative method. Journal of Pharmacy Research, 4:1711-17112.

Patel, C.V., Khandhar, A.P., Captain, A.D., Patel, K.T. (2007) Validated absorption factor spectrophotometric and reversed-phase high performance liquid chromatographic methods for the determination of ramipril and olmesartan medoxomil in pharmaceutical formulations. Eurasian Journal of Analytical Chemistry, 2(3): 159-171.

Pournima Patil, Vaishali Barge, Harinath More, Sachin Piswikar. (2011) Spectrophotometric Method for Simultaneous determination of Olmesartan medoxomil and Amlodipine besylate from Tablet Dosage Form. International Journal of Current Pharmaceutical Research; 3:74 79.

Rekha Gangola, Sunil Kaushik, Paras Sharma. (2011) Spectrophotometric Simultaneous determination of Hydrochlorothiazide and Telmisartan in Combined Dosage Form, Journal of Applied Pharmaceutical Science; 01:46-49.

Syed Shanaz Qutab, Syed Naeem Razzaqa, Muhammad Ashfaq, Islam Ullah Khan, Ahmad Mahmood Mumtaz. (2009) Simultaneous Quantitation of Olmesartan medoxomil and Amlodipine besylate in Combined Tablets Using HPLC. Journal of the Chilean Chemical Society; 54:234237. [DOI]
Tarte, PS, Wate, SP, Khedikar, PB, Satpure, BT, Pawnikar, G. (2008) Simultaneous Estimation of Nebivolol and Hydrochlorothiazide in Combined Tablet Dosage Form by Multicomponent Mode of Analysis. Asian Journal of Research in Chemistry; 1(2):77-79.

The Merck Index, 23rd ed. Whitehouse Station, New Jersey. 516,6235

Vachhani Kevin H, Patel Satish A. (2011) Development and validation of Spectrophotometric method for simultaneous estimation of metoprolol succinate and Olmesartan medoxomil in Tablet. Journal of Applied Pharmaceutical Science; 01:112-115.

Vijaya Vichare, Vrushali Tambe, Vrushali Kashikar, Dhole S.N. (2011) Spectrophotometric Simultaneous Determination of Amlodipine Besylate and Hydrochlorothiazide In Combined Tablet Dosage Form By Simultaneous Equation, Absorption Ratio and First Order Derivative Spectroscopy Methods. International Journal of Chemistry; 2:7-10.

Wankhede, S.B., Tajne, M.R., Gupta, K.R., Wadodkar, S.G. (2007) RP-HPLC Method for Simultaneous Estimation of Telmisartan \& Hydrochlorothiazide in Tablet Dosage Forms. Indian Journal of Pharmaceutical Sciences; 69:298300. [DOI]

Zaveri Maitreyi, Khandhar Amit. (2010) Development and Validation of a RP-HPLC for the Simultaneous Estimation of Atenolol and Hydrochlorothiazide in Pharmaceutical Dosage Forms. International Journal of Advances in Pharmaceutical Sciences; 1:167-171. 